\title{
UPTAKE AND INCORPORATION OF AMINO ACIDS BY THE PREIMPLANTATION MOUSE EMBRYO
}

\author{
R. L. BRINSTER \\ Laboratory of Reproductive Physiology, School of Veterinary Medicine, \\ University of Pennsylvania, Philadelphia, Pennsylvania, U.S.A. \\ (Received 23rd November 1970, revised 19th April 1971)
}

Summary. Uptake and incorporation were determined for glutamine and asparagine as well as for nine amino acids which have been shown by culture experiments in vitro to be important in the development of the preimplantation mouse embryo. In general, there was a tenfold increase in the incorporation and a fivefold increase in uptake of the amino acids from the one-cell to the morula stage. The largest change in both incorporation and uptake occurred at about the eight-cell stage of development.

Leucine was incorporated more, and glutamine taken up in larger quantities, than the other amino acids. The rate of incorporation of leucine carbon into the embryo between the one- and two-cell stage was 0.208 and for the morula to blastocyst was $2 \cdot 153 \mathrm{pmol} / \mathrm{embryo} / \mathrm{hr}$. The total uptake of glutamine carbon between the one- and two-cell stage was 1.768 and between the morula and blastocyst was 5.655 $\mathrm{pmol} / \mathrm{embryo} / \mathrm{hr}$.

Fertilization of the mouse ovum did not significantly affect incorporation of leucine and had only a small effect on total uptake of leucine. This contrasts with the findings in invertebrates where fertilization results in a marked increase in all aspects of amino acid metabolism.

\section{INTRODUCTION}

Autoradiographic studies have shown that some amino acids are taken up by the mouse embryo, beginning at fertilization and continuing through cleavage. The rate of uptake is low during the first few cleavage stages but increases after the formation of true nucleoli (Mintz, 1964). Attempts have been made to estimate quantitatively the rate of uptake (total amount of amino acid carbon taken up) and incorporation (amount of amino acid carbon included in large molecules) of radioactive amino acids (Monesi \& Salfi, 1967; Tasca \& Hillman, 1970), but the studies have not reported the amount of amino acid in moles that is taken up or incorporated by the embryo at various developmental stages. In addition, the relative rate of uptake and incorporation of different amino acids by the mouse embryo has not been examined.

The present studies were designed to provide quantitative data on the uptake and incorporation of several amino acids which were considered to be important to embryo development on the basis of culture studies in vitro (Brinster, 
1965a; Brinster \& Thomson, 1966). The final experiments in this series compared the rate of amino acid uptake and incorporation by unfertilized and fertilized ova. There is known to be a marked difference in amino acid incorporation between unfertilized and fertilized ova of the echinoderms (Hultin, 1952), but it is not known if the same situation is true in mammalian ova.

\section{MATERIALS AND METHODS}

Embryos were obtained from 6- to 8-week-old random-bred Swiss female mice which were superovulated and mated with Swiss male mice. When unfertilized ova were used, the females were not mated. The methods used for collecting and handling the embryos have been described (Brinster, 1963, 1970). The culture medium used in the manipulations of the embryos was Brinster's Medium for Ovum Culture-2 (BMOG-2) (Brinster, 1965b, 1970). Cumulus cells were completely removed from fertilized and unfertilized ova by treatment with hyaluronidase; before being placed in the experimental culture medium, the embryos were washed three times by sequential transfer, in a volume of $5 \mu \mathrm{l}$, through three changes of medium ( $3 \mathrm{ml} \mathrm{BMOC-2}$ ).

The experimental culture medium was prepared by adding the amino acid to be studied to BMOC-2. The optimum concentration of amino acid for development was determined in each case by preliminary culture experiments as described previously for various other substrates (Brinster, 1963, 1965b). Four groups of twelve two-cell embryos were placed in each concentration of a series of dilutions $\left(10^{-2} \mathrm{M}, 5 \times 10^{-3} \mathrm{M}, 10^{-3} \mathrm{M}\right.$ and $\left.5 \times 10^{-4} \mathrm{M}\right)$ of the amino acid contained in BMOC-2 in which the bovine serum albumin (BSA) was replaced by Ficoll, a non-metabolizable polymer of sucrose. The amino acid being tested was then the only amino nitrogen source in the medium. The concentration in which the embryos showed the best development, as judged by the number of cleavages, was considered the optimum concentration.

Uniformly labelled amino acids (specific activity between 1 and $3 \mathrm{mCi}$ / $\mathrm{mmol}$ ) were added at their optimum concentration to BMOC-2 or BMOC-2 containing Ficoll in place of BSA, and droplets of the medium were placed under liquid paraffin in culture dishes (Brinster, 1963). In some cases, dimethyl silicone fluid (Dow Corning 200) with a viscosity of 50 centistokes was substituted for the liquid paraffin. There is no difference in embryo development between cultures under paraffin oil and under silicone. Between fifteen and twenty embryos were placed in each drop, and the dishes were placed in the incubator for 20 to $24 \mathrm{hr}$ in most experiments. At the end of the culture period, the embryos which had undergone normal development, as judged by the occurrence of cleavage and the morphological appearance of the cells, were collected and rapidly washed by sequential transfer in $5 \mu l$ of medium through three changes of BMOG-2 (3 ml) containing cold (non-radioactive) amino acid in the same concentration as in the experimental medium. The embryos were then transferred in $5 \mu \mathrm{l}$ of the final wash to a $2-\mathrm{ml}$ centrifuge tube containing $100 \mu \mathrm{l}$ of water to cause lysis of the embryo cells. The tube was frozen and thawed three times and was agitated on a mixer during each thawing to assure complete breakdown of the cytoplasmic structure. One $\mathrm{mg}$ of bovine 
serum albumin and $1 \mathrm{mg}$ of glycogen in $20 \mu \mathrm{l}$ of water were added to the tube to act as cold carrier. (The unlabelled albumin and glycogen carrier molecules dilute the labelled compounds of the embryo and markedly reduce the loss of these labelled compounds during experimental manipulations.) One hundred $\mu \mathrm{l}$ of $10 \%$ trichloroacetic acid (TCA) was added to the tubes, the contents mixed, and the tube centrifuged (1000 $\mathrm{g}$ for $3 \mathrm{~min}$ ). The TCA supernatant was drawn off and saved, and the precipitate was resuspended in $200 \mu \mathrm{l}$ of $5 \%$ TCA. The tube was centrifuged (1000 $\mathrm{g}$ for $3 \mathrm{~min}$ ), and the TCA supernatant was drawn off and added to the first supernatant. The precipitate (acid insoluble) was dissolved in $100 \mu \mathrm{l}$ of $10 \% \mathrm{KOH}$ and placed in a scintillation vial. One $\mathrm{ml}$ of Beckman Biosolve no. 1 and $10 \mathrm{ml}$ of scintillation fluid were added to the vial. To the pooled TCA supernatants (approximately $400 \mu \mathrm{l}$ ) drawn off during the above procedure and containing the acid soluble material was added $600 \mu 1$ of $95 \%$ ethyl alcohol. The alcohol and TCA were mixed and centrifuged. The alcohol precipitate was washed again in $95 \%$ alcohol, and aliquots of the supernatant fluid were saved for scintillation counting. The precipitate was dissolved in $100 \mu \mathrm{l}$ of water and prepared for counting as described for the precipitate above. The scintillation fluid contained $0.5 \%$ $(\mathrm{w} / \mathrm{v}), 2,5$-diphenyloxazole (PPO) and $0.03 \%(\mathrm{w} / \mathrm{v}), 1,4$-bis-2 (4-methyl-5phenyloxazolylbenzene) $\left(\mathrm{M}_{2} \mathrm{POPOP}\right)$ in toluene.

In the experiments comparing incorporation and uptake of amino acid carbon from unfertilized and fertilized ova, the mice to be used as a source of ova were injected intraperitoneally with 5 i.u. HCG exactly $20 \mathrm{hr}$ before the ova were collected. If fertilized ova were needed, the females were placed with fertile males $6 \mathrm{hr}$ before the ova were collected. Under these conditions, approximately $75 \%$ of the ova were fertilized. Since ovulation is known to occur between 11 and $14 \mathrm{hr}$ (Edwards \& Gates, 1959) after injection of HCG, the ova were assumed to be approximately $8 \mathrm{hr}$ postovulation at the time of the experiment. The ova were incubated for $1 \mathrm{hr}$ in medium containing $1 \mathrm{mg} / \mathrm{ml}$ of albumin and $10^{-2} \mathrm{M}$ radioactive leucine.

In all, six different groups of experiments were performed to study the accumulation of amino acid carbon by the mouse embryo. In the first group of experiments, embryos were cultivated in a medium containing radioactive leucine as the only amino acid. In the second group of experiments, radioactive glutamine was added to the medium instead of leucine. Although development in the culture system had been used to determine the optimum concentration of all the amino acids used in these experiments, several experiments were performed to determine the effect of concentration of leucine or glutamine on accumulation of the amino acid, and these experiments comprised the third group. In the fourth group of experiments, the accumulation of carbon from several other amino acids important for development of the mouse embryo was determined by the same methods as used for leucine. In the next experiments, Group 5, the effect of macromolecules on leucine accumulation was measured, and in the final experiments, Group 6, a comparison was made between accumulation of leucine by the unfertilized and fertilized ovum.

In all experiments, total uptake of amino acid carbon was considered to be the sum of the carbon in the acid-insoluble (incorporated) and acid-soluble 
fractions (total uptake $=$ incorporated + acid soluble). In those cases where the acid-soluble fraction was treated with alcohol, the resulting precipitate was considered to be mostly glycogen but was not shown to be completely devoid of all nitrogen. In all experiments, the amount of radioactive carbon was measured in each fraction and, on the basis of this measurement, the amount of the amino acid carbon in the fraction was calculated.

\section{RESULTS}

The results of the first group of experiments, in which the accumulation of leucine carbon by the embryo was determined, are shown in Table 1 . The

TABLE 1

CARBON ACCUMULATION FROM LEUCINE BY THE PREIMPLANTATION MOUSE EMBRYO

\begin{tabular}{|c|c|c|c|c|c|c|}
\hline \multirow[b]{2}{*}{$\begin{array}{c}\text { Period of } \\
\text { development }\end{array}$} & \multirow[b]{2}{*}{$\begin{array}{l}\text { Culture } \\
\text { medium }\end{array}$} & \multirow[b]{2}{*}{ Exp. } & \multicolumn{4}{|c|}{ Carbon accumulated } \\
\hline & & & $\begin{array}{l}\text { Acid insoluble } \\
\text { (Incorporated) }\end{array}$ & $(\text { ETOH } p p t)^{A}$ & $\begin{array}{l}\text { cid soluble } \\
\text { (ETOH supernatant) }\end{array}$ & $\begin{array}{l}\text { Total } \\
\text { uptake }\end{array}$ \\
\hline \multirow[t]{2}{*}{ One-cell to two-cell } & & $\begin{array}{l}1 \\
2\end{array}$ & $\begin{array}{l}0 \cdot 224 \\
0 \cdot 191\end{array}$ & $\begin{array}{l}0.001 \\
0.006\end{array}$ & $\begin{array}{l}0.513 \\
0.411\end{array}$ & $\begin{array}{l}0.738 \\
0.608\end{array}$ \\
\hline & Ficoll & $\begin{array}{l}1 \\
2\end{array}$ & $\begin{array}{l}0.175 \\
0.197\end{array}$ & $\begin{array}{l}0.000 \\
0.000\end{array}$ & $\begin{array}{l}0.414 \\
0.343\end{array}$ & $\begin{array}{l}0.589 \\
0.540\end{array}$ \\
\hline \multirow[t]{2}{*}{ Two-cell to four-cell } & Albumin & $\begin{array}{l}1 \\
2\end{array}$ & $\begin{array}{l}0 \cdot 168 \\
0.255\end{array}$ & $\begin{array}{l}0.004 \\
0.004\end{array}$ & $\begin{array}{l}0.492 \\
0.302\end{array}$ & $\begin{array}{l}0 \cdot 664 \\
0 \cdot 561\end{array}$ \\
\hline & Ficoll & $\begin{array}{l}1 \\
2\end{array}$ & $\begin{array}{l}0 \cdot 167 \\
0 \cdot 193\end{array}$ & $\begin{array}{l}0.000 \\
0.003\end{array}$ & $\begin{array}{l}0.454 \\
0.305\end{array}$ & $\begin{array}{l}0.621 \\
0.501\end{array}$ \\
\hline \multirow[t]{2}{*}{ Eight-cell to morula } & Albumin & $\begin{array}{l}1 \\
2\end{array}$ & $\begin{array}{l}0.966 \\
1.333\end{array}$ & $\begin{array}{l}0.010 \\
0.008\end{array}$ & $\begin{array}{l}1.171 \\
0.667\end{array}$ & $\begin{array}{l}2 \cdot 147 \\
2 \cdot 008\end{array}$ \\
\hline & Ficoll & $\begin{array}{l}1 \\
2\end{array}$ & $\begin{array}{l}0 \cdot 753 \\
0 \cdot 685\end{array}$ & $\begin{array}{l}0.004 \\
0.000\end{array}$ & $\begin{array}{l}0 \cdot 364 \\
0.408\end{array}$ & $\begin{array}{l}1 \cdot 121 \\
1.093\end{array}$ \\
\hline \multirow[t]{2}{*}{ Morula to blastocyst } & Albumin & $\begin{array}{l}1 \\
2\end{array}$ & $\begin{array}{l}2 \cdot 048 \\
2 \cdot 257\end{array}$ & $\begin{array}{l}0.037 \\
0.016\end{array}$ & $\begin{array}{l}2 \cdot 441 \\
2 \cdot 314\end{array}$ & $\begin{array}{l}4 \cdot 526 \\
4 \cdot 587\end{array}$ \\
\hline & Ficoll & $\begin{array}{l}1 \\
2\end{array}$ & $\begin{array}{l}2 \cdot 165 \\
2 \cdot 047\end{array}$ & $\begin{array}{l}0.029 \\
0.024\end{array}$ & $\begin{array}{l}2 \cdot 639 \\
2 \cdot 478\end{array}$ & $\begin{array}{l}4 \cdot 833 \\
4 \cdot 549\end{array}$ \\
\hline
\end{tabular}

Values expressed in pico atoms of carbon/embryo/hr. Albumin medium contained $1 \mathrm{mg} / \mathrm{ml}$ bovine serum albumin in addition to $10^{-2} \mathrm{M}$-leucine. In the Ficoll medium, the synthetic, non-metabolizable polymer Ficoll replaced the albumin.

incorporation (acid-insoluble fraction) and total uptake of leucine were approximately the same for the one-cell fertilized embryo and the two-cell embryo. The first significant increase in uptake and incorporation was by the eight-cell embryo during its development into a morula. The rate of incorporation was about four times greater during this $24-\mathrm{hr}$ period than it was during the first and second 24-hr period of embryonic development. Incorporation as well as total uptake of leucine continued to increase as the embryo developed and was about ten times as great during the development of the morula as it was during the development of the zygote. An analysis of variance indicated that there was no significant difference between uptake or incorporation of leucine into the embryo regardless of whether incubation was in albumin 
medium or Ficoll medium. In the latter medium, there was no amino nitrogen source other than the leucine whereas, in the albumin medium, the protein could serve as a source of amino nitrogen. There was very little amino acid carbon in the ethyl alcohol precipitate fraction (mostly glycogen) at any of the stages.

In the second group of experiments, glutamine replaced the leucine in the culture medium and the results are shown in Table 2. An analysis of variance showed no significant difference between the effect of Ficoll and albumin medium on uptake or incorporation of glutamine. In several experiments, a comparison was made between one-cell ova which cleaved and those that did not. Incorporation and uptake were not significantly affected by the failure of the embryos to cleave either in glutamine or in other amino acids.

A comparison of the results in Table 1 and Table 2 indicates that although the total uptake of glutamine was considerably higher at every stage of develop-

TABLE 2

GARBON ACGUMULATION FROM GLUTAMINE BY THE PREIMPLANTATION MOUSE EMBRYO

\begin{tabular}{|c|c|c|c|c|c|}
\hline \multirow[b]{2}{*}{$\begin{array}{c}\text { Period of } \\
\text { development }\end{array}$} & \multirow[b]{2}{*}{$\begin{array}{l}\text { Culture } \\
\text { medium }\end{array}$} & \multicolumn{4}{|c|}{ Carbon accumulated } \\
\hline & & $\begin{array}{l}\text { Acid insoluble } \\
\text { (Incorporated) }\end{array}$ & $(E T O H p p t)$ & $\begin{array}{l}\text { lcid soluble } \\
\text { (ETOH supernatant) }\end{array}$ & $\begin{array}{l}\text { Total } \\
\text { uptake }\end{array}$ \\
\hline One-cell to two-cell & $\begin{array}{l}\text { Albumin } \\
\text { Ficoll* }\end{array}$ & $\begin{array}{l}0.130 \\
0.098\end{array}$ & $\begin{array}{l}0.007 \\
0.005\end{array}$ & $\begin{array}{l}1 \cdot 809 \\
1 \cdot 487\end{array}$ & $\begin{array}{l}1.946 \\
1.590\end{array}$ \\
\hline Two-cell to four-cell & $\begin{array}{l}\text { Albumin } \\
\text { Ficoll }\end{array}$ & $\begin{array}{l}0.202 \\
0.183\end{array}$ & $\begin{array}{l}0.009 \\
0.007\end{array}$ & $\begin{array}{l}1 \cdot 376 \\
1 \cdot 260\end{array}$ & $\begin{array}{l}1.587 \\
1.450\end{array}$ \\
\hline Eight-cell to morula & $\begin{array}{l}\text { Albumin } \\
\text { Ficoll }\end{array}$ & $\begin{array}{l}0.752 \\
0.725\end{array}$ & $\begin{array}{l}0.011 \\
0.011\end{array}$ & $\begin{array}{l}2 \cdot 005 \\
2 \cdot 109\end{array}$ & $\begin{array}{l}2 \cdot 768 \\
2 \cdot 846\end{array}$ \\
\hline Morula to blastocyst & $\begin{array}{l}\text { Albumin } \\
\text { Ficoll }\end{array}$ & $\begin{array}{l}1 \cdot 202 \\
1 \cdot 009\end{array}$ & $\begin{array}{l}0.039 \\
0.026\end{array}$ & $\begin{array}{l}5 \cdot 390 \\
3 \cdot 644\end{array}$ & $\begin{array}{l}6 \cdot 631 \\
4.679\end{array}$ \\
\hline
\end{tabular}

Values expressed in pico atoms of carbon/embryo/hr. Albumin medium contained $1 \mathrm{mg} / \mathrm{m}$. bovine serum albumin in addition to $5 \times 10^{-3} \mathrm{M}$-glutamine. In the Ficoll medium, the albumin was replaced with Ficoll.

* The embryos lived but did not cleave. Consequently, one-cell stages were used for the assay.

ment than uptake of leucine, incorporation of leucine was higher than incorporation of glutamine at all stages. The amount of radioactivity in the ethyl alcohol precipitate (glycogen or other polysaccaride) was relatively low for both amino acids at all the developmental stages.

From these first two studies, it appeared that incorporation and uptake of amino acids by mouse embryos showed a marked change at about the eight-cell stage, as has been indicated by other workers. Therefore, it seemed that quantitative data on two periods, the one-cell to two-cell development period and the morula to blastocyst development period, would provide much of the interesting information on the utilization of any amino acid without examining the other two periods of development, the two-cell to four-cell and eight-cell to morula periods of development. For this reason, most subsequent studies involved one-cell and morula-stage embryos. Likewise, the ethyl alcohol- 
precipitated radioactivity provided little additional information and was not determined in most of the subsequent studies.

In the third group of experiments, the effect of amino acid concentration was examined and the results of these experiments are shown in Table 3. Reducing the amino acid concentration from $10^{-2} \mathrm{M}$ to $10^{-4} \mathrm{M}$ had very little effect on the incorporation of carbon from leucine into one-cell embryos even though the non-incorporated (TCA-soluble) carbon from leucine in the embryo decreased by $95 \%$. Likewise, there was only about a $25 \%$ decrease in carbon from

TABLE 3

EFFECT OF CONGENTRATION ON THE AGCUMULATION OF LEUGINE AND GLUTAMINE BY THE MOUSE EMBRYO

\begin{tabular}{|c|c|c|c|c|}
\hline \multirow{2}{*}{$\begin{array}{c}\text { Period of } \\
\text { development }\end{array}$} & \multirow{2}{*}{$\begin{array}{c}\text { Amino acid and } \\
\text { concentration } \\
(\text { mol/litre })\end{array}$} & \multicolumn{3}{|c|}{ Carbon accumulated } \\
\hline & & $\begin{array}{c}\text { Acid } \\
\text { insoluble }\end{array}$ & $\begin{array}{c}\text { Acid } \\
\text { soluble }\end{array}$ & $\begin{array}{l}\text { Total } \\
\text { uptake }\end{array}$ \\
\hline \multirow[t]{3}{*}{ One-cell to two-cell } & Leucine $10^{-2}$ & $\begin{array}{l}0.190 \\
0.210\end{array}$ & $\begin{array}{l}0.297 \\
0.298\end{array}$ & $\begin{array}{l}0.487 \\
0.508\end{array}$ \\
\hline & Leucine $10^{-3}$ & $\begin{array}{l}0.173 \\
0.185\end{array}$ & $\begin{array}{l}0.036 \\
0.052\end{array}$ & $\begin{array}{l}0.209 \\
0.237\end{array}$ \\
\hline & Leucine $10^{-4}$ & $\begin{array}{l}0.175 \\
0 \cdot 190\end{array}$ & $\begin{array}{l}0.005 \\
0.013\end{array}$ & $\begin{array}{l}0.180 \\
0 \cdot 203\end{array}$ \\
\hline \multirow[t]{3}{*}{ Morula to blastocyst } & Leucine $10^{-2}$ & $\begin{array}{l}2 \cdot 011 \\
1.924\end{array}$ & $\begin{array}{l}2 \cdot 289 \\
2 \cdot 392\end{array}$ & $\begin{array}{l}4 \cdot 300 \\
4 \cdot 316\end{array}$ \\
\hline & Leucine $10^{-3}$ & $\begin{array}{l}1.530 \\
1.780\end{array}$ & $\begin{array}{l}1.595 \\
1.038\end{array}$ & $\begin{array}{l}3 \cdot 125 \\
2 \cdot 818\end{array}$ \\
\hline & Leucine $10^{-4}$ & $\begin{array}{l}1 \cdot 455 \\
1 \cdot 491\end{array}$ & $\begin{array}{l}0.703 \\
0.717\end{array}$ & $\begin{array}{l}2 \cdot 162 \\
2 \cdot 208\end{array}$ \\
\hline \multirow[t]{3}{*}{ One-cell to two-cell } & Glutamine $5 \times 10^{-3}$ & $\begin{array}{l}0.139 \\
0.145\end{array}$ & $\begin{array}{l}1.520 \\
1.608\end{array}$ & $\begin{array}{l}1.659 \\
1.753\end{array}$ \\
\hline & Glutamine $10^{-3}$ & $\begin{array}{l}0.087 \\
0.090\end{array}$ & $\begin{array}{l}0.721 \\
0.742\end{array}$ & $\begin{array}{l}0.808 \\
0.832\end{array}$ \\
\hline & Glutamine $10^{-4}$ & $\begin{array}{l}0.046 \\
0.059\end{array}$ & $\begin{array}{l}0 \cdot 131 \\
0.125\end{array}$ & $\begin{array}{l}0 \cdot 177 \\
0 \cdot 184\end{array}$ \\
\hline \multirow[t]{3}{*}{ Morula to blastocyst } & Glutamine $5 \times 10^{-3}$ & $\begin{array}{l}1.285 \\
1.075\end{array}$ & $\begin{array}{l}5 \cdot 043 \\
4 \cdot 313\end{array}$ & $\begin{array}{l}6 \cdot 328 \\
5 \cdot 488\end{array}$ \\
\hline & Glutamine $10^{-3}$ & $\begin{array}{l}1 \cdot 219 \\
1 \cdot 169\end{array}$ & $\begin{array}{l}4 \cdot 094 \\
3 \cdot 747\end{array}$ & $\begin{array}{l}5 \cdot 313 \\
4.916\end{array}$ \\
\hline & Glutamine $10^{-4}$ & $\begin{array}{l}0.755 \\
0.860\end{array}$ & $\begin{array}{l}1.675 \\
1.870\end{array}$ & $\begin{array}{l}2 \cdot 430 \\
2 \cdot 726\end{array}$ \\
\hline
\end{tabular}

Values expressed in pico atoms of carbon/embryo/hr.

leucine incorporation into the morula when the concentration of leucine in the medium was reduced to $10^{-4} \mathrm{M}$. The reduction in TGA-soluble carbon from leucine decreased by about $70 \%$ over the same range. The effect of concentration on incorporation and uptake of carbon from glutamine was similar to that seen for leucine in the morula, but incorporation of leucine into the one-cell embryos was less affected by concentration of substrate than was incorporation of glutamine. Neither uptake nor incorporation of carbon from leucine or glutamine decreased in proportion to the decrease in concentration of the 
substrate in the medium. Incorporation was maintained well even when substrate concentration was reduced to $1 \%$ or $2 \%$ of the optimal concentration determined for development in vitro.

The results of the fourth group of experiments in which carbon accumulation from several other amino acids was measured are shown in Table 4. For comparison, the accumulation of carbon from pyruvate and glucose which was previously recorded (Brinster, 1969) is also shown. Of the amino acids examined, carbon from leucine and arginine was incorporated to the greatest extent by the one-cell embryos. Uptake of glutamine was twice as great as uptake of any of the other amino acids at the one-cell stage of development. At the

\section{TABLE 4}

GARBON ACCUMULATION FROM AMINO ACIDS BY THE PREIMPLANTATION MOUSE EMBRYO

\begin{tabular}{|c|c|c|c|c|c|}
\hline \multirow[b]{3}{*}{ Substrate } & \multirow[b]{3}{*}{$\begin{array}{c}\text { Concentration } \\
(\text { mol/litre })\end{array}$} & \multicolumn{4}{|c|}{ Period of development } \\
\hline & & \multicolumn{2}{|c|}{ One-cell to two-cell } & \multicolumn{2}{|c|}{ Morula to blastocyst } \\
\hline & & $\underset{\text { insoluble }}{\text { Acid }}$ & $\begin{array}{c}\text { Acid } \\
\text { soluble }\end{array}$ & $\underset{\text { insoluble }}{\text { Acid }}$ & $\begin{array}{l}\text { Acid } \\
\text { soluble }\end{array}$ \\
\hline Leucine & $10^{-2}$ & 0.208 & 0.465 & $2 \cdot 153$ & $2 \cdot 404$ \\
\hline Arginine & $10^{-2}$ & 0.220 & 0.675 & $1.248 \dagger$ & $1.844 \dagger$ \\
\hline Glycine & $10^{-2}$ & 0.070 & 0.790 & $1 \cdot 152$ & $2 \cdot 218$ \\
\hline Alanine & $10^{-2}$ & 0.087 & 0.651 & - & - \\
\hline Glutamine & $5 \times 10^{-3}$ & 0.114 & 1.654 & $1 \cdot 105$ & $4 \cdot 550$ \\
\hline Glutamate & $5 \times 10^{-3}$ & 0.097 & 0.165 & $1 \cdot 376$ & 4.744 \\
\hline Aspartate & $5 \times 10^{-3}$ & $0 \cdot 091$ & 0.096 & $1 \cdot 394$ & $3 \cdot 653$ \\
\hline Asparagine & $5 \times 10^{-3}$ & 0.099 & $1 \cdot 161$ & & - \\
\hline Methionine & $5 \times 10^{-3}$ & $0 \cdot 108$ & 0.216 & $0 \cdot 610$ & $2 \cdot 129$ \\
\hline Cystine & $10^{-3}$ & 0.040 & 0.103 & 0.749 & 1.669 \\
\hline Histidine & $10^{-3}$ & 0.051 & $0 \cdot 181$ & $0 \cdot 326$ & $1 \cdot 311$ \\
\hline Pyruvate* & $5 \times 10^{-4}$ & 0.279 & 0.482 & 0.869 & 0.924 \\
\hline Glucose* & $5 \times 10^{-3}$ & $1 \cdot 114$ & 0.534 & $3 \cdot 372$ & $16 \cdot 636$ \\
\hline
\end{tabular}

Values expressed in pico atoms of carbon/embryo/hr. Substrate added to medium containing $1 \mathrm{mg} / \mathrm{ml}$ albumin. All values are the mean of at least two experiments.

* From Brinster (1969).

$\dagger$ Substrate concentration $=10^{-3} \mathrm{M}$. The embryos dies in $10^{-2} \mathrm{M}$ radioactive arginine.

morula stage, incorporation of leucine carbon and uptake of glutamine carbon were higher than the other amino acids examined. Surprisingly, incorporation of carbon from pyruvate at the one-cell stage was higher than incorporation of carbon from any amino acid, even though the concentration of pyruvate in the medium was about one-tenth that of most of the amino acids. Glucose carbon had the highest rate of incorporation at all developmental stages of any of the substrates shown.

In the fifth group of experiments, the effect of the addition of foetal calf serum on leucine carbon accumulation was examined. Neither $10 \%$ whole foetal calf serum nor $10 \%$ dialysed foetal calf serum significantly affected either incorporation or total uptake. The macromolecules and other components of the serum did not facilitate the passage of leucine into the embryo nor did they increase 
the incorporation of the carbon from the leucine into the protein of the embryo.

In the sixth group of experiments, the effect of fertilization on leucine accumulation was examined and these results are shown in Table 5. There was no significant difference in incorporation between unfertilized and fertilized ova $\left(t_{8}=1 \cdot 12\right)$. However, there was a small but significant $\left(t_{8}=2.51\right.$; $0.05>P>0.02)$ increase in total uptake of leucine carbon by the fertilized ova.

TABLE 5

INCORPORATION AND UPTAKE OF GARBON FROM LEUCINE BY UNFERTILIZED AND FERTILIZED MOUSE OVA

\begin{tabular}{c|cc|cc}
\hline \multirow{3}{*}{ Exp. } & \multicolumn{4}{|c}{ Developmental stage at incubation } \\
\cline { 2 - 5 } & \multicolumn{2}{|c|}{ Unfertilized } & \multicolumn{2}{|c}{ Fertilized } \\
& $\begin{array}{c}\text { Acid } \\
\text { insoluble }\end{array}$ & Total uptake & $\begin{array}{c}\text { Acid } \\
\text { insoluble }\end{array}$ & Total uptake \\
\hline 1 & 0.378 & 1.466 & 0.417 & 1.870 \\
2 & 0.404 & 1.315 & 0.367 & 1.953 \\
3 & 0.346 & 1.542 & 0.348 & 1.555 \\
4 & 0.394 & 1.845 & 0.334 & 2.046 \\
5 & 0.360 & 1.140 & 0.277 & 1.729 \\
Mean & 0.376 & 1.462 & 0.348 & 1.831 \\
S.E. & $\pm \mathbf{0 . 0 1 2}$ & $\pm \mathbf{0 . 1 1 8}$ & \pm 0.022 & \pm 0.087 \\
\hline
\end{tabular}

Values expressed in pico atoms of carbon/ovum/hr. Culture medium contained $1 \mathrm{mg} / \mathrm{ml}$ albumin and $10^{-2}$ M-leucine. Incubation time was $1 \mathrm{hr}$.

\section{DISGUSSION}

The experiments with leucine and with glutamine show a level rate of uptake and incorporation of the amino acids by the embryo up to about the eight-cell stage of development, after which there is a steady increase in both uptake and incorporation. This confirms the autoradiographic studies of Mintz (1964) and the studies of Monesi \& Salfi (1967) and Tasca \& Hillman (1970) in which incorporation was reported in counts/min/embryo. These findings suggest that only a few new proteins are formed during early cleavage. After the eight-cell stage, the metabolic rate goes up (Mills \& Brinster, 1967), RNA synthesis increases (Ellem \& Gwatkin, 1968; Woodland \& Graham, 1969; Pikó, 1970), and protein content increases (Brinster, 1967). Amino acid incorporation might, therefore, be expected to increase in the last half of the preimplantation period, and it does.

The carbon from the amino acids examined in this study was not incorporated at the one-cell stage and early cleavage stages to as great an extent as carbon from pyruvate. Even so, the major portion of pyruvate is not incorporated but oxidized. Incorporation of pyruvate carbon is only $4.0 \%$ at the one-cell stage and $7.3 \%$ at the morula stage of oxidation of pyruvate carbon (Brinster, 1969). However, the incorporation of carbon from amino acids increases more than incorporation of carbon from pyruvate or glucose. This 
suggests that the increase in amino acid incorporation reflects a more specific synthetic change than just a general increase in metabolic activity.

Perhaps amino acid incorporation into protein is a relatively minor part of the overall metabolism of the embryo during early cleavage but becomes more important in later cleavage, particularly after morula formation. However, the tenfold increase in rate of incorporation between early and late cleavage does not necessarily mean that protein synthesis increases to this degree. Changes in permeability of the embryo to amino acids could change the specific activity of the internal amino acid pool which could account for part of the change in incorporation rate. In addition, the relatively small effect of amino acid concentration in the medium on incorporation may indicate that active transport processes as well as modified permeability influence the rate of incorporation. Changes in enzyme pathways within the embryo could also affect the formation of metabolic products from the amino acids and thereby influence incorporation rates. Perhaps, changes in the ratio of incorporated carbon to total uptake represent a more accurate estimate of changes in an amino acid's use in protein synthesis than does the incorporation rate alone.

An important finding in the studies with leucine and glutamine is that neither albumin nor serum in the medium affects the incorporation or the uptake of the amino acids. Since embryos develop normally in medium containing albumin as the only amino nitrogen source (Brinster, 1965a), the lack of incorporation of amino acids from albumin suggests that the embryos do not need very much exogenous amino acid for development. The albumin and serum protein may function to prevent leakage of endogenous amino acids by stabilizing the cell membrane. Additional evidence that exogenous amino acids may not be essential for development of the mouse embryo has recently been obtained by Cholewa \& Whitten (1970), who were able to grow two-cell mouse embryos in media devoid of any amino nitrogen source. However, amino acids and proteins are present in the normal environment of the embryo in vivo and are thus available for use. The studies with labelled amino acids provide some information about the rates at which the amino acids might be used at different developmental stages and perhaps about the relative rates of protein synthesis.

The studies of Monesi \& Salfi (1967) with the mouse and Manes \& Daniel (1969) with the rabbit suggest an increase in amino acid incorporation at the time of fertilization, but it is not possible to determine from their data whether the increase occurred in more than one experiment since no estimate of variance was given. However, the present studies indicate no difference in incorporation and very little difference in uptake between unfertilized and fertilized mouse ova. This finding is in sharp contrast to the situation in invertebrate embryos where fertilization is characterized by a marked increase in the incorporation of amino acids (Hultin, 1952; Nakano \& Monroy, 1958; Hultin \& Bergstrand, 1960). The absence of an increase in amino acid incorporation at fertilization in the mouse ovum suggests that enhancement of protein synthesis is not a characteristic of fertilization in the mouse ovum as it is in the sea urchin. An activation of protein synthesis, comparable to that which occurs in the sea urchin at fertilization, may occur in mammals in response to luteinizing hormone or at some stage in oocyte maturation. 


\section{ACKNOWLEDGMENTS}

This investigation was supported by PHS Research Grant 03071 from the National Institute of Child Health and Human Development. I wish to thank Mrs Mary R. Avarbock for her excellent technical assistance.

\section{REFERENCES}

BRINSTER, R. L. (1963) A method for in vitro cultivation of mouse ova from two-cell to blastocyst. Expl Cell Res. 32, 205.

Brinster, R. L. (1965a) Studies on the development of mouse embryos in vitro. III. The effect of fixed-nitrogen source. 7. exp. Zool. 158, 69.

Brinster, R. L. (1965b) Studies on the development of mouse embryos in vitro. IV. Interaction of energy sources. F. Reprod. Fert. 10, 227.

Brinster, R. L. (1967) Protein content of the mouse embryo during the first five days of development. F. Reprod. Fert. 13, 413.

BRINsteR, R. L. (1969) The incorporation of carbon from glucose and pyruvate into the preimplantation mouse embryo. Expl Cell Res. 58, 153.

Brinster, R. L. (1970) In vitro culture of mammalian ova. In: Advances in the Biosciences 4. Ed. G. Raspe. Pergamon Press, Oxford.

Brinster, R. L. \& Thomson, J. L. (1966) Development of eight-cell mouse embryos in vitro. Expl Cell Res. 42, 308.

Cholewa, J. A. \& Whitten, W. K. (1970) Development of two-cell mouse embryos in the absence of a fixed-nitrogen source. F. Reprod. Fert. 22, 553.

Edwards, R. G. \& Gates, A. H. (1959) Timing of the stages of the maturation divisions, ovulation, fertilization and the first cleavage of eggs of adult mice treated with gonadotrophins. F. Endocr. $18,292$.

Ellem, K. A. O. \& Gwatkin, R. B. L. (1968) Patterns of nucleic acid synthesis in the early mouse embryo. Devl Biol. 18, 311.

Hultin, T. (1952) Incorporation of $\mathrm{N}^{15}$-labeled glycine and alanine into the proteins of developing sea urchin eggs. Expl Cell Res. 3, 494.

Hultin, T. \& Bergstrand, A. (1960) Incorporation of $\mathrm{C}^{14}$-L-leucine into protein by cell-free systems from sea urchin embryos at different stages of development. Devl Biol. 2, 61 .

Manes, G. \& Daniel, J. C., JR (1969) Quantitative and qualitative aspects of protein synthesis in the preimplantation rabbit embryo. Expl Cell Res. 55, 261.

MiLls, R. M., JR \& BRINSTER, R. L. (1967) Oxygen consumption of preimplantation mouse embryos. Expl Cell Res. 47, 337.

Mintz, B. (1964) Synthetic processes and early development in the mammalian egg. F. exp. Zool. 157, 85.

Monesi, V. \& SALfi, V. (1967) Macromolecular syntheses during early development in the mouse embryo. Expl Cell Res. 46, 632.

NAKano, E. \& Monrox, A. (1958) Incorporation of $\mathrm{S}^{35}$-methionine in the cell fractions of sea urchin eggs and embryos. Expl Cell Res. 14, 236.

Pikó, L. (1970) Synthesis of macromolecules in early mouse embryos cultured in vitro: RNA, DNA and a polysaccharide component. Devl Biol. 21, 257.

TASCA, R. J. \& Hillman, N. (1970) Effects of actinomycin D and cycloheximide on RNA and protein synthesis in cleavage stage mouse embryos. Nature, Lond. 225, 1022.

Woodland, H. R. \& Graham, G. F. (1969) RNA synthesis during early development of the mouse. Nature, Lond. 221, 327. 